\title{
Molecular genetic analysis of stygobiotic shrimps of the genus Xiphocaridinella (Crustacea: Decapoda: Atyidae) reveals a connection between distant caves in Central Abkhazia, southwestern Caucasus
}

\author{
Ivan Marin (D ${ }^{1^{*}}$ and Ilya Turbanov (D) ${ }^{2,3}$ \\ ${ }^{1}$ 1A.N. Severtsov Institute of Ecology and Evolution of RAS, Leninsky prospect, 33, Moscow, 119071, Russia \\ ${ }^{2}$ I.D. Papanin Institute of Biology of Inland Waters of RAS, Borok, 109, Nekous District, Yaroslav region, 152742, Russia \\ ${ }^{3}$ Cherepovets State University, Lunacharskogo, 5, Cherepovets, Vologda region, 162602, Russia
}

\begin{abstract}
Based on the morpho-genetic study of stygobiotic shrimps from the genus Xiphocaridinella Sadowsky, 1930 (Crustacea: Decapoda: Atyidae), a hydrogeological connection of a number of distant caves in Central Abkhazia of the southwestern Caucasus is satisfied, which indicates the possibility of using biospeleological studies in some cases to identify karst hydrosystems together with traditional hydrogeological methods. Moreover, a new stygobiotic atyid shrimp from the genus Xiphocaridinella, X. kelasuri sp. n., is described based on morphology and analysis of mitochondrial cytochrome oxidase I DNA sequences from three distant caves. The new species is genetically divergent from relatives and phylogenetically related to Xiphocaridinella smirnovi Marin, 2020, described from the Besletka (=Tskaro) Cave. Recently, the number of described speciesof the genus Xiphocaridinella from Caucasus has increased to 13 species, while the diversity of Xiphocaridinella found in the Besletka Cave is increasing to three species, which is higher than in any other known cave where Troglocaris-like shrimps have been discovered.
\end{abstract}

Keywords: $\quad$ DNA barcoding, stygobiotic, shrimps, hydrogeology, Caucasus

Received 28 January 2021; Revised 14 September 2021; Accepted 19 September 2021

Citation: Marin I., Turbanov I., 2021. Molecular genetic analysis of stygobiotic shrimp of the genus Xiphocaridinella (Crustacea: Decapoda: Atydae) reveals a connection between distant caves in Central Abkhazia, southwestern Caucasus. International Journal of Speleology, 50(3), 301-311. https://doi.org/10.5038/1827-806X.50.3.2378

\section{INTRODUCTION}

The Caucasus is one of the most diverse areas of the world in terms of the diversity of terrestrial (troglo-) and aquatic (stygobiotic) cave-dwelling specialized fauna. This is, in particular, due to the large area of karst areas/the number of caves, their great depth and geological complexity that, probably favoring the processes of speciation and radiation into a high diversity of subterranean habitats.

Amtkel karst system is located in the mid-mountain part of the Kodor River basin (Central Abkhazia, southwestern Caucasus), and displays a particularly complex geological history with developed Cretaceous and Paleogene karst formations, underlain and overlain by non-karst deposits of the Middle Jurassic and Paleogene formations (Amelichev et al., 1990, 2007). The sediments are crushed into a gentle synclinal fold and cut through the valleys of the high-water (13-15 $\mathrm{m}^{3} / \mathrm{s}$ ) transit Amtkel and Dzampal rivers. However, their tributaries, the Azanta and Shakuran rivers, are characterized by low water, the flow in which is observed only after heavy rains. Several dozen karst cavities of various types are known within the area (Tintilozov, 1976).

After the earthquake of 1891, the Amtkel landslide lake $\left(43^{\circ} 05^{\prime} 37.0^{\prime \prime N} 41^{\circ} 17^{\prime} 52.7^{\prime \prime} \mathrm{E}\right)$ was formed on the Amtkel River, which led to a significant restructuring of the hydrogeological regime of the area (Amelichev et al., 1990, 2007). Most of the Amtkel River valley below the landslide dam was drained, making the channel caves previously flooded by the river, now acting as ponor caves, became available for speleological research. At the base of the blockage of the Amtkel Lake formed the Tsivtskala Karst Spring (4304'37.3"N 4118'26.2”E), whose waters passing through the valley drained over 1-1.5 $\mathrm{km}$ away, absorbed into the channel ponor caves - Pakchuchaya, Kholodnaya (=Kamnepadnaya), Vodopadnaya (=Bolshaya Medveditsa) and others. Significant fluctuations in the water level in the lake 
for 40-50 $\mathrm{m}$ determined sharp differences in the flooding regime of all local caves (Amelichev et al., 1990, 2007).

Hydrologically and karstologically, the cave clusters concentrated on the Amtkel and Dzampal rivers, as well as their tributaries, have long been considered isolated from each other (Gigineiyshvili, 1979). Since then, the Amtkel karst aquifer system with highly dynamic groundwater flow (velocity $\sim 1.5 \mathrm{~km} / \mathrm{h}$ ) and a considerable length (about $10 \mathrm{~km}$ ) was discovered, with the probable final point of the whole karst systems in the karst Shavtskala (=Amtkelskaya, Karasu) Cave (4301'15.7'N 41 '20'23.7”E) (Amelichev et al., 1990, 2007).

However, there is an assumption that part of the underground karst water from the Amtkel karst system goes to the southwest, towards the Kelasur River Valley (Kiknadze, 1978), where in the lower reaches of the river there is a cluster of caves, with the largest Kelasurskaya (=Alexandrovskaya) Cave (4302'48.8”N 4109'36.0”E) (Kipiani \& Tintilizov, 1960; Dublyansky et al., 1987). The underground watercourse in this cave has no connection with the surface waters of the Kelasur River, except during the flooding periods, when the waters of the Kelasur River enter the cave through the ponors located upstream of the river. At the same time, the main water source of the underground river flowing in the Kelasurskaya Cave remains unknown. In addition, experiments on fluorescein (dioxifluorane) staining of the underground watercourse in the Kelasurskaya Cave showed its connection with the Besletka (=Tskaro) Cave $\left(43^{\circ} 01^{\prime} 48.1^{\prime \prime} \mathrm{N} 41^{\circ} 04^{\prime} 36.0 " \mathrm{E}\right)$, located near the dam on the Besletka (=Basla) River (Kipiani \& Tintilizov, 1960; Tatashidze et al., 2009).

The stygobiotic atyid shrimp genus Xiphocaridinella Sadowsky, 1930 (Crustacea: Decapoda: Atyidae) currently includes 12 valid species described in the subterranean water habitats of the SW Caucasus (e.g., Sadowsky, 1930; Birštein, 1939, 1948; Juzbašjan, 1940, 1941; Marin \& Sokolova, 2014; Marin, 2017a, b, 2018a, b, 2019a, b, 2020). At the same time, knowledge about these stygobiotic shrimps living in underground (subterranean) habitats of the Kolkhida coastal lowland plain of the Eastern Black Sea region, or Colhis, is still incomplete (e.g., Marin \& Sinelnikov, 2017), and new species have been discovered and described to date. Three stygobiotic Xiphocaridinella species are known from Sukhum and Gulripsh regions of Central Abkhazia (Fig. 6): X. osterloffi (Juzbaš'jan, 1941) from the Nizhne-Shakuranskaya (=Lower Shakuran) Cave (4301'47.8”N 41 20 '02.0”E) (Juzbaš’jan 1940, 1941), X. falcirostris Marin, 2020 from the Nizhne-Shakuranskaya and Besletka caves (Marin, 2020) and X. smirnovi Marin, 2020 from the Besletka Cave (Marin, 2020).

In the course of study the stygobiotic fauna of Central Abkhazia, molecular-genetic analysis of Xiphocaridinella shrimps revealed the presence of an undescribed species occurring in several distant caves, such as Pakchuchaya and Kelasurskaya, as well as one specimen of the same species was found the in the samples collected in traps installed at the entrance of the Besletka Cave during a powerful flood in May 2017 (Marin, 2020). This species is described herewith as a new to science. Moreover our results also revealed a hydrogeological connection between geographically distant caves clusters of the Atmel karst system (Amelichev et al., 2007). Thus, the biospeleological method of identification of karst hydrologic systems, based on morphological and molecular genetic studies of stygobiotic animals, significantly expands the knowledge about the hydrogeological connections of underground watercourses within Central Abkhazia, located in the basins of the Kodor, Kelasur and Besletka rivers, whose surface water drains are not connected.

\section{MATERIAL AND METHODS}

\section{Sampling and repositories}

Shrimps were collected by hand net in the subterranean streams of the Abkhazian underground caves, inside the Pakchuchaya $\left(43^{\circ} 03^{\prime} 52.3^{\prime \prime} \mathrm{N}\right.$ $41^{\circ} 18 ' 32.1$ 'E) and Kelasurskaya $\left(43^{\circ} 02^{\prime} 48.8^{\prime \prime N}\right.$ $41^{\circ} 09^{\prime} 36.0^{\prime} \mathrm{E}$ ) caves in September 2014, and using a large net fixed at the entrance of the Besletka Cave $\left(43^{\circ} 01^{\prime} 48.1^{\prime \prime N} 41^{\circ} 04^{\prime} 36.0^{\prime} \mathrm{E}\right)$ in May 2017. Research does not include endangered or protected species. All specimens were preserved and stored in 90\% solution of ethanol for further morphological and DNA analysis.

The type and additional materials is deposited in the: Zoological Museum of Moscow University (ZMMU), Moscow, Russia; Laboratory of Ecology and Evolution of Marine Invertebrates, A.N. Severtsov Institute of Ecology and Evolution of Russian Academy of Sciences (LEMMI), Moscow, Russia.

\section{Morphological study}

The morphology study and drawings were performed using an light microscope Olympus SZX16 with an attached camera lucida. Postorbital carapace length (pcl., in $\mathrm{mm}$ ), the length from the posterior orbit to the posterodorsal margin of carapace, and total body length (tbl., in $\mathrm{mm}$ ), dorsal length from the tip of rostrum till the distal margin of telson, were used as standard measurements.

\section{DNA extraction}

Local endemism of closely related species in separate cave systems is quite common and even characteristic for the genus Troglocaris s. 1. (Sket \& Zakšek, 2009), including Xiphocaridinella (Marin, 2017a, b, 2018a, b, 2019a, b, 2020). Thus, it is very convenient to use the cytochrome c oxidase subunit I (COI) mtDNA gene marker, in order to unravel potential species complexes within the group (Avise, 1993). The markers has been proving as extremely informative in previous studies at both population and species level (e.g., Marin, 2017a, b, 2018a, b, 2019a, b, 2020). Total genomic DNA was extracted from muscle tissue using the innuPREP DNA Micro Kit (AnalitikJena, Germany). The COI mtDNA gene marker was amplified with the using of the universal primers LCO1490 (5'GGTCAACAAATCATAAAGATATTGG-3') and HC02198 (5'-TAAACTTCAGGGTGACCAAAAAATCA-3') (Folmer 
et al., 1994). Polymerase chain reaction (PCR) were performed on an amplificator T100 (Bio-Rad, USA) under the following conditions: initial denaturation at $96^{\circ} \mathrm{C}$ for $1.5 \mathrm{~min}$ followed by 42 cycles of $95^{\circ} \mathrm{C}$ for $2 \mathrm{~min}, 49^{\circ} \mathrm{C}$ for $35 \mathrm{sec}$, and $72^{\circ} \mathrm{C}$ for $1.5 \mathrm{~min}$. Each chain reaction was concluded by an extension step, set at $72^{\circ} \mathrm{C}$ for $7 \mathrm{~min}$. The volume of $10 \mu \mathrm{L}$ of reaction mixture contained $1 \mu \mathrm{L}$ of total DNA, $2 \mu \mathrm{L}$ of $5 \mathrm{xPCR}$ mix (Dialat, Russia), $1 \mu \mathrm{L}$ of each primer and $5 \mu \mathrm{L}$ of $\mathrm{H}_{2} \mathrm{O}$. The amplification products were separated by using gel electrophoresis of nucleic acids on a $1.5 \%$ agarose gel in 1xTBE, and then stained and visualized with $0.003 \%$ EtBr using imaging UV software. PCR products were then sequenced using Genetic Analyzer ABI 3500 (Applied Biosystems, USA) and BigDye 3.1 (Applied Biosystems, USA) with forward and reverse primers. Dataset of aligned sequences of COI mtDNA gene markers, about 617 base pairs in length used in the study were taken from GenBank (NCBI) (Table 1) and author data.

Table 1. The list of nucleotide sequences of the Caucasian Xiphocaridinella spp. and outgroup shrimps used for moleculargenetic analysis taken from GenBank (NCBI).

\begin{tabular}{|c|c|}
\hline Species & GenBank (NCBI) \\
\hline Xiphocaridinella ablaskiri (Birštein, 1939) & MN117923, MN117924 \\
\hline Xiphocaridinella dbari Marin, 2019 & MK875787, MN117920 \\
\hline Xiphocaridinella fagei (Birštein, 1939) & MN105983, MN105984 \\
\hline Xiphocaridinella falcirostris Marin, 2020 & МТ066033-МТ066038 \\
\hline Xiphocaridinella jusbaschjani (Birštein, 1948) & MN105985, MN117919 \\
\hline Xiphocaridinella kumistavi (Marin, 2017) & MF287654, MF287652, MF287653 \\
\hline Xiphocaridinella kutaissiana Sadowsky, 1930 & MF287657, MF287655, MF287656 \\
\hline Xiphocaridinella motena Marin, 2019 & MN105981, MN105982 \\
\hline Xiphocaridinella osterloffi Juzbašjan, 1940 & MN117921, MN117922, MT065905-MT065909 \\
\hline Xiphocaridinella otapi Marin, 2018 & MN117925, MN117926 \\
\hline Xiphocaridinella shurubumu Marin, 2018 & MN105986, MN105987 \\
\hline Xiphocaridinella smirnovi Marin, 2020 & MT066032 \\
\hline \multicolumn{2}{|c|}{ Outgroup } \\
\hline Spelaeocaris kapelana Sket \& Zakšek, 2009 & DQ320038 \\
\hline Spelaeocaris neglecta Sket \& Zakšek, 2009 & DQ320048 \\
\hline Spelaeocaris hercegovinensis (Babic, 1922) & DQ320044 \\
\hline Spelaeocaris pretneri (Matjašič, 1956) & DQ641556 \\
\hline Troglocaris anophthalmus (Kollar, 1848) & DQ641547, DQ320042 \\
\hline Troglocaris planinesis (Birštein, 1984) & DQ641534 \\
\hline Troglocaris sp. Croatia & DQ320039 \\
\hline Atyaephyra desmaresi (Millet, 1831) & DQ641570 \\
\hline Gallocaris inermis (Fage, 1937) & DQ641568 \\
\hline Dugastella marocana Bouvier, 1912 & FJ594347 \\
\hline Dugastella valentina (Ferrer Galdiano, 1924) & DQ641569 \\
\hline
\end{tabular}

\section{Phylogenetic analysis}

Consensus of complementary sequences was obtained with MEGA 7.0 (Kumar et al., 2016). PartitionFinder v. 2. (Lanfear et al., 2016) was used for finding bestfitting partitions for the concatenated dataset as COI mtDNA is usually characterized by a strong heterogeneity in nucleotide substitution rates among all three coding positions. The GTR+G+I and GTR+G+I evolutionary substitution models was suggested as the best by the Akaike Information Criterion (12599.244) using jModeltest2.1.141. Different evolutionary substitution models and phylogenetic estimates were widely congruent in this study. Further RAxML (https://raxml-ng.vitalit.ch) (Kozlov et al., 2019) with 1000 bootstrap replicates was used to create Maximum Likelihood (ML) phylogenies used for visualization. Maximum likelihood bootstrap values (MLBV) are given above each node. Pairwise genetic divergences ( $p$-distances) were calculated based on COI sequences using MEGA 7.0 with the Kimura 2-Parameter (K2P) model of evolution (Kimura, 1980). Median joint network (Bandelt et al., 1999) was reconstructed with PopArt (Population Analysis with Reticulate Trees) software (Leigh \& Bryant, 2015).

\section{Graphic materials}

The map of distribution of stygobiotic shrimps of the genus Xiphocaridinella (Fig. 6) was drawn in ArcGIS 10.8. The construction of the map was accomplished with the help of SRTM 90m DEM v.4 (https://srtm.csi.cgiar.org/) for the altitude data, and HydroATLAS - for rivers (Linke et al., 2019); the final processing of the map was performed in Inkscape v.1.0.1.

\section{Acronyms}

ZMMU, Zoological Museum of Moscow State University, Moscow, Russia; LEMMI, Laboratory of Ecology and Evolution of Marine Invertebrates, A.N. Severtsov Institute of Ecology and Evolution of Russian Academy of Sciences, Moscow, Russia. 


\section{RESULTS}

\section{DNA analysis of Xiphocaridinella}

The final dataset for the analysis included 237 sequences, displaying 44 variable (polymorphic) sites, of which 29 were parsimony informative. The interspecific pairwise genetic distances ( $p$-distances) in the population of Xiphocaridinella kelasuri sp. $\mathrm{n}$. from the Pakchuchaya ( $\mathrm{n}=11)$, the Kelasurskaya $(\mathrm{n}=7)$ and the Besletka $(\mathrm{n}=1)$ caves is minimal and close to 0.004 ( $\mathrm{n}=19$ ), which clearly indicates that they belong to the same species (Sket \& Zakšek, 2009; Marin, 2017a, b, 2018a, b, 2019a, b, 2020).

The intraspecific p-distances between Xiphocaridinella kelasurisp.n. $(\mathrm{n}=19)$ and other Caucasian Xiphocaridinella species are more 0.06 substitutions per 100 nucleotide positions (more than 6\%), which makes it possible to distinguish it as a valid species (see Table 2; Fig. 1) (after Knowlton et al., 1993; Knowlton \& Weigt, 1998; Hebert et al., 2003; Sites \& Marshall, 2004; Zakšek et al., 2006; Lefébure et al., 2006b; Marin, 2017a, b, 2018a, b, 2019a, b, 2020).

The phylogenetic reconstruction (COI mtDNA gene marker) of the Caucasian Xiphocaridinella (see Fig. 1) confirmed the monophyly of the genus Xiphocaridinella (Bayesian - PP = 1.00; ML-BS = $1.0(100 \%))$. The new species represent the well-isolated sister clade to Xiphocaridinella smirnovi Marin, 2020 known from the Besletka Cave $\left(43^{\circ} 01^{\prime} 48.1^{\prime \prime} \mathrm{N} 41^{\circ} 04^{\prime} 36.0^{\prime \prime} \mathrm{E}\right)$ (Marin, 2020), neighboring to the Kelasurskaya Cave.

Table 2. Pairwise genetic (COI mtDNA) distances ( $p$-distances $\pm \mathrm{SE}$ ) between Xiphocaridinella kelasuri sp. $n .(n=5)$ and known Caucasian species of the genus Xiphocaridinella.

\begin{tabular}{|l|l|}
\hline Xiphocaridinella smirnovi $(\mathrm{n}=1)$ & $0.062 \pm 0.009$ \\
Xiphocaridinella kumistavi $(\mathrm{n}=18)$ & $0.078 \pm 0.010$ \\
Xiphocaridinella otapi $(\mathrm{n}=18)$ & $0.080 \pm 0.011$ \\
Xiphocaridinella shurubumu $(\mathrm{n}=15)$ & $0.088 \pm 0.011$ \\
Xiphocaridinella falcirostris $(\mathrm{n}=11)$ & $0.092 \pm 0.012$ \\
Xiphocaridinella osterloffi $(\mathrm{n}=35)$ & $0.092 \pm 0.012$ \\
Xiphocaridinella dbari $(\mathrm{n}=7)$ & $0.097 \pm 0.013$ \\
Xiphocaridinella fagei $(\mathrm{n}=17)$ & $0.098 \pm 0.013$ \\
Xiphocaridinella abraskiri $(\mathrm{n}=5)$ & $0.099 \pm 0.014$ \\
Xiphocaridinella motena $(\mathrm{n}=10)$ & $0.100 \pm 0.014$ \\
Xiphocaridinella jusbaschjani $(\mathrm{n}=14)$ & $0.102 \pm 0.014$ \\
Xiphocaridinella kutaissiana $(\mathrm{n}=16)$ & $0.106 \pm 0.014$ \\
\hline
\end{tabular}
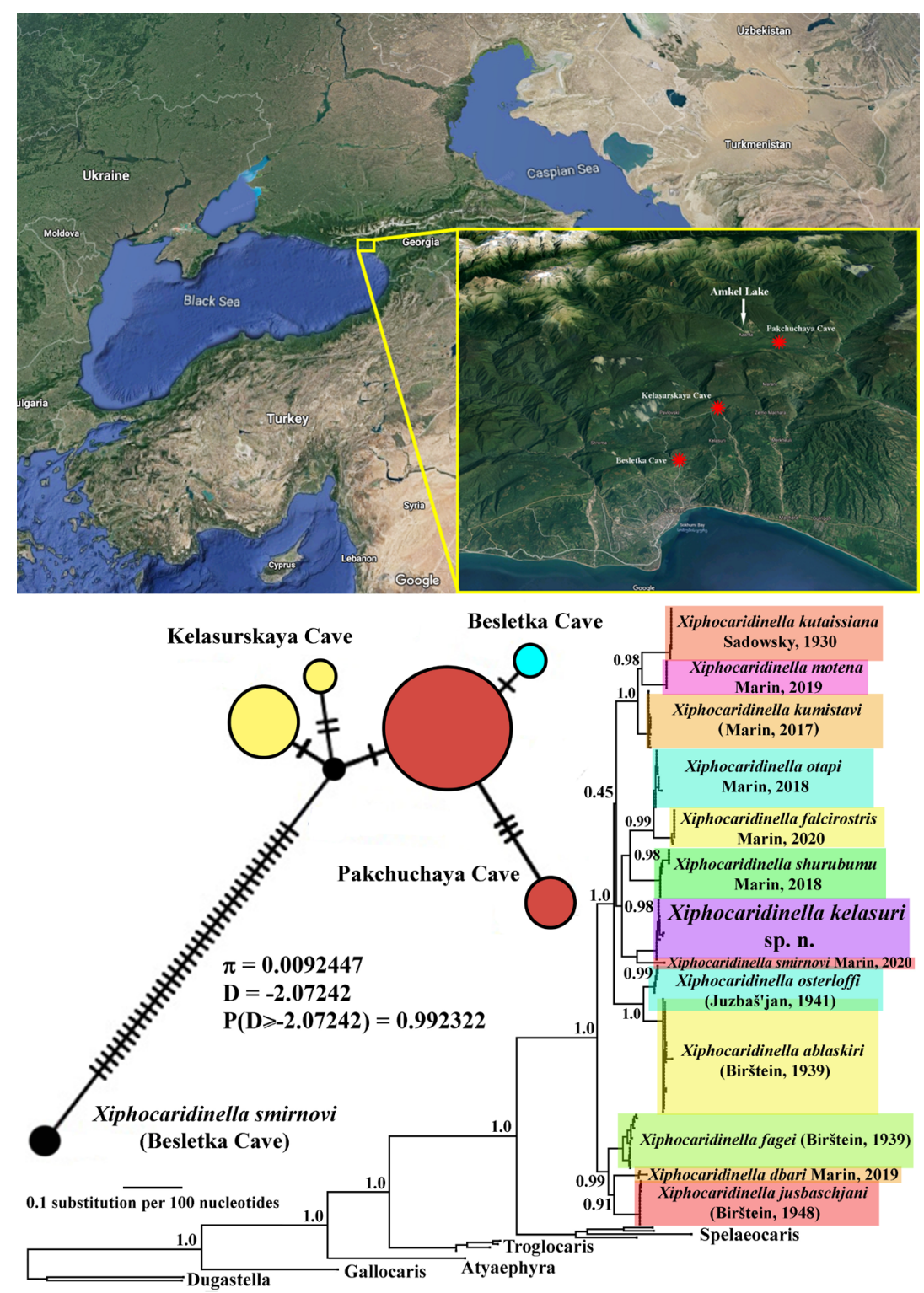

Fig. 1. The map indicating the locality where shrimps where collected (upper), median joint network and phylogenetic reconstruction (COI mtDNA gene marker) using RAxML and best partitioning scheme resulting from a PartitionFinder v.2 analysis of the Caucasian Xiphocaridinella with the Maximum likelihood bootstrap values (MLBV) presented above each node (lower). 
Taxonomic part and species description

Order Decapoda Latreille, 1802

Family Atyidae De Haan, 1849

Genus Xiphocaridinella Sadowsky, 1930

Xiphocaridinella kelasuri sp. n.

urn:1sid:zoobank.org:act:4CCC3898-D1D3-4370B9E5-FE8C45AB7ABC

(Figs 2-5)

Type material. HOLOTYPE, $ᄋ$ (pcl. $5.2 \mathrm{~mm}$, tbl. 16.0 $\mathrm{mm})$, ZMMU Ma-6203, SW Caucasus, Abkhazia, Gulripsh District, Pakchuchaya Cave, 4303'52.3"N 41 18'32.1"E, about 308-310 $\mathrm{m}$ above sea level (asl), in subterranean stream at the bottom of the cave $(-40$ $\mathrm{m}$ asl from the entrance), coll. I. Turbanov, 18 Sept. 2014. PARATYPES: $1 \hat{\jmath}$ (pcl. $3.9 \mathrm{~mm}$, tbl. $13.0 \mathrm{~mm}$ ), ZMMU Ma-6204, SW Caucasus, Abkhazia, Gulripsh District,

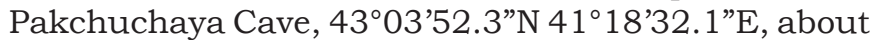
308-310 $\mathrm{m}$ above sea level (asl), in subterranean stream at the bottom of the cave $(-40 \mathrm{~m}$ asl from the entrance), coll. I. Turbanov, 18 Sept. 2014; 1 ㅇ (pcl. $5.4 \mathrm{~mm}$, tbl. $18.0 \mathrm{~mm}$ ), ZMMU Ma-6205, 10ิ (pcl. 5.3 mm, tbl. $17.0 \mathrm{~mm}$ ), ZMMU Ma-6206, SW Caucasus, Abkhazia, Gulripsh District, Kelasurskaya Cave, 4302'48.8"N 4109'36.0"E, about 195-200 $\mathrm{m}$ asl, in subterranean stream at the bottom of the cave $(-95 \mathrm{~m}$ asl from the entrance), coll. I. Turbanov, 04 Sept. 2014.

Additional material. 5우, $7 \hat{\jmath}$, LEMMI, SW Caucasus, Abkhazia, Gulripshi District, Pakchuchaya Cave, 4303'52.3"N 4118'32.1"E, about 308-310 m asl, in subterranean stream at the bottom of the cave $(-40$ $\mathrm{m}$ asl from the entrance), coll. I. Turbanov, 18 Sept.

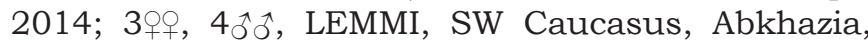
Gulripsh District, Kelasurskaya Cave, 4302'48.8'N 41 $1^{\circ} 09^{\prime} 36.0$ " $\mathrm{E}$, about $195-200 \mathrm{~m}$ asl, in subterranean stream at the bottom of the cave $(-95 \mathrm{~m}$ asl from the entrance), coll. I. Turbanov, 04 Sept. 2014; 1 damaged ô (pcl. $6.5 \mathrm{~mm}$, tbl. $20.0 \mathrm{~mm})$, LEMMI, Abkhazia, Sukhum District, Besletka Cave, $43^{\circ} 01^{\prime} 48.1^{\prime \prime} \mathrm{N}$ $41^{\circ} 04^{\prime} 36.0^{\prime \prime} \mathrm{E}$, about $68-70 \mathrm{~m}$ asl, collected with net in a stream flowing from the cave entrance in the period of high water, coll. I. Marin \& S. Sinelnikov, 25 May 2017.

Description. Small-sized shrimp with swollen subcylindrical body. Carapace (Fig. 2d, e, g) smooth, with small dorsal tubercle in frontal part and well developed supraorbital teeth (Fig. 2c, f). Rostrum variable in different individuals (Figs 2, 3), relatively long, slender in distal part and sharply pointed distally, lanceolate, sometimes turned forward or upward, reaching the midlength or distal margin of basal antennular segment, with developed lateral lamina, unarmed or armed dorsally with small fixed teeth in the distal part and several movable spines in its medial part.

Abdominal somites smooth, unarmed; tergites non-carinate, without dorsal lobes, not posteriorly produced; pleura of pleomeres I-IV posteroventrally and ventrally rounded, distoventral margins of pleomere VI sharply produced posterodorsally. Telson (Fig. 4i, j) about 3 times as long as wide proximally, slightly expanded distally, usually with 2 , but sometimes with 3 pairs of slender dorsal spines, inserted at about 0.4 and 0.7 telson length, respectively; distal margin convex, with 5 pairs of distal spines (Fig. 4k).

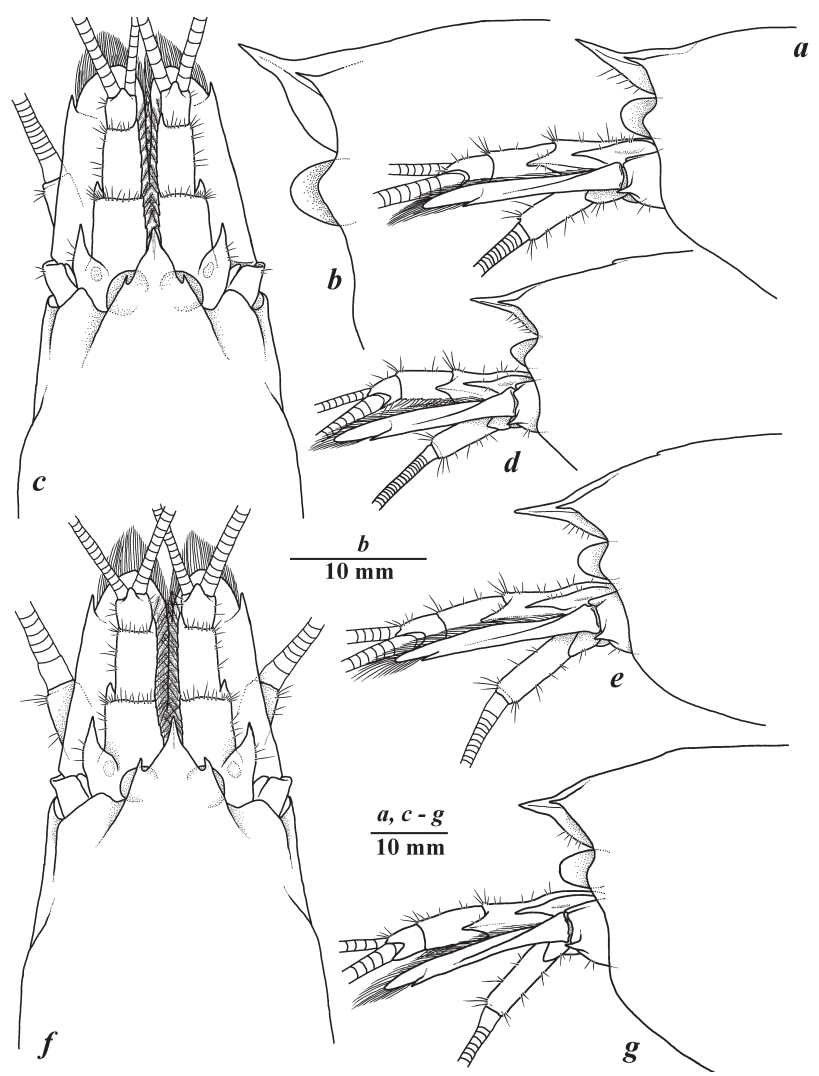

Fig. 2. Xiphocaridinella kelasuri sp. nov., Pakchuchaya Cave, Central Abkhazia, southwestern Caucasus: ${ }^{\lambda}$, pcl. $5.1 \mathrm{~mm}$, tl. $16 \mathrm{~mm}$, LEMMI (a, b); holotype, o, pcl. $5.2 \mathrm{~mm}$, tbl. $16.0 \mathrm{~mm}$, ZMMU Ma- Ma-6203 (c, d); paratype, $\widehat{\jmath}$, pcl. 3.9 mm, tbl. 13.0 mm, ZMMU Ma-6204 (e, f); q, pcl. 5.4 mm, tl. 18 mm, LEMMI (g); front of carapace, dorsal (c, f) and lateral views (a, b, d, e, and $\mathrm{g}$ )

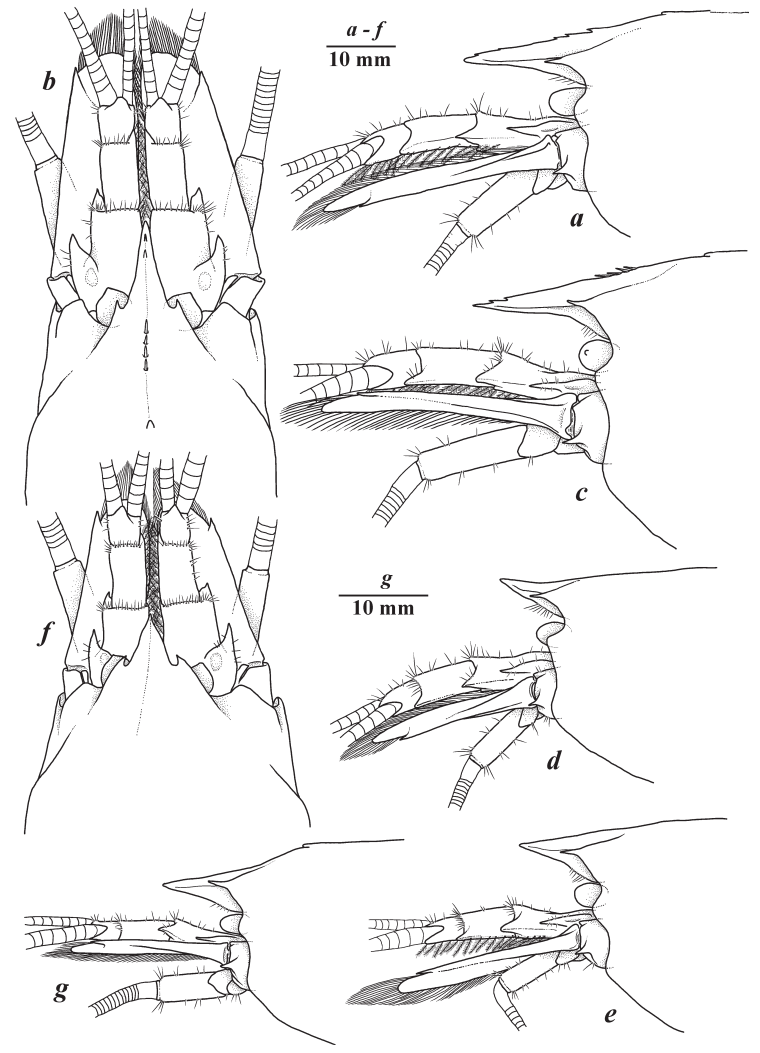

Fig. 3. Xiphocaridinella kelasuri sp. nov., Kelasurskaya

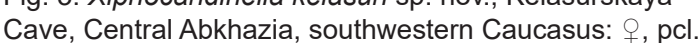
$5.8 \mathrm{~mm}$, tl. $19 \mathrm{~mm}$, LEMMI (a, b), \&, pcl. $6.0 \mathrm{~mm}$, tl. $20 \mathrm{~mm}$, LEMMI (c), +, pcl. 5.4 mm, tbl. 18.0 mm, ZMMU Ma-6205 (d); đ, pcl. $5.3 \mathrm{~mm}$, tbl. 17.0 mm, ZMMU Ma-6206 (e, f); 웅, pcl. $5.3 \mathrm{~mm}$, tl. $17 \mathrm{~mm}$, LEMMI (g); front of carapace, dorsal (b, f) and lateral views (a, c, d, e, and g). 
Eyes (Figs 2, 3) partly reduced, swollen, subcylindrical, partly covered by carapace; cornea rounded and feebly marked, without pigment; eyestalk stout, swollen, cylindrical, about as long as wide.

Antennula (Fig. 4a) with robust basal peduncular segment, about twice longer than proximal width, without ventromedial tooth, distolateral angle with broadly produced sharp projection (Fig. 4b); stylocerite short, sharpening distally, not reaching the distal margin of basal segment; second and third segments stout, unarmed; second segment about 1.8 times as long as wide and about 1.5-2 times as long as distal segment; distal segment about as long as wide.

Antenna with basicerite stout, about 1.5 times as wide as long, with distolateral margin unarmed; carpocerite robust, about 1.5 times as long as wide, not reaching midlength of scaphocerite; scaphocerite (Figs 2, 3) well developed, broad, with small but wellmarked distolateral tooth, lamella bluntly rounded distally.

Mouthparts characteristic for the genus, without specific features. Mandible well developed, without palp; molar process well developed, relatively slender, with several small and large distodorsal teeth; incisor process slender, tapering distoventrally, with slender serrated sharp lamina distally. Maxillula with welldeveloped simple palp armed with 2 setae distally, well developed, produced, blunt distally, dorsal lobe with completely fused lacinia, ventral lobe small, covered with curved setae distally. Maxilla normal, with simple tapering small palp; endites stout, well developed; basal endite feebly bilobed, furnished with elongated stiff setae; coxal endite obsolete; scaphognathite broad, furnished with short plumose setae. Maxilliped I normal; epipod small, reduced; exopodite small and slender, with expanded caridean lobe bearing plumose marginal setae; basal and coxal endites completely fused, excavate, furnished with long simple setae distally. Maxilliped II with relatively robust segments; without epipod; exopodite slender overreaching propodal segment, with long plumose setae distally; distolateral margin of propodus straight, dorsal margin convex, furnished with slender setae; dactylus about twice as long as broad, with straight distal margin, with numerous medium stout spines and numerous simple spines along distal margin. Maxilliped III slender, with small epipodite and arthrobranch; exopodite slender, almost reaching the distal margin of antepenultimate segment; antepenultimate segment slender, about 8 times as long as wide; penultimate segment about $7-8$ times as long as wide, with straight lateral margins; ultimate (distal) segment slender, about 7 times as long as wide, tapering distally, with tufts of short simple stick-like setae along ventral and lateral margins.

Pereiopods I (Figs 4c, 5a) with basis about as long as wide; coxa with well-developed slender epipodite and tuft of setobranchs; basis about as long as wide, with well-developed exopodite overreaching carpo-meral articulation; ischium about 2-2.5 times longer than wide; merus slender, about 4 times as long as wide, about 1.5 times longer than ischium and equal to carpus; carpus relatively stout in males and slightly more slender in females, significantly widening distally in females, about as 2.5-4 times as long as maximal width; palm relatively stout, about as long as wide, subcylindrical in cross-section; fingers stout, subcylindrical, about 3.5-4 times as long as proximal width, armed with a row of stout strong plumose setae.

Pereiopods II (Figs 4d, 5b) with relatively slender segments, longer than pereipods I; coxa with welldeveloped slender epipodite and tuft of setobranchs; basis about as long as wide, with relatively short exopodite reaching carpo-meral articulation; ischium about 3.5-4 times as long as wide; merus slender, about 5 times as long as wide, longer than ischium and equal to carpus; carpus relatively slender, about 5.5-6 times as long as wide, slightly widening distally; palm relatively stout, similar to palm of pereiopod I, about as long as wide, subcylindrical in crosssection; fingers relatively stout, subcylindrical, blunt distally, about 4 times as long as proximal width, with simple and straight cutting edge, with a row of strong plumose setae.

Pereiopod III in males (Fig. 4e) relatively slender; coxa with tuft of setobranchs and small epipodite; basis about as long as wide, with well-marked exopodite overreaching carpo-meral articulation; ischium about 2 times as long as wide, with wellmarked distoventral spine; merus about 6 times as long as wide, with 4 or 5 well-marked spines along ventral margin; carpus relatively slender, about 6 times as long as wide, slightly widening distally, about twice shorter than merus and propodus, with small subdistal spine; propodus about 11 times as long as wide, with straight margins, armed with 4-5 spines along proximal half of ventral margin and dense row of small simple setae in distal half of ventral margin; dactylus (Fig. 4f) about 4 times longer than maximal wide, biunguiculate, ventral margin armed with dense row of small simple setae, main unguis smooth, curved and sharp; accessory unguis triangular, sharp, larger than ventral spines, about twice shorter than main unguis. Pereiopod III in females (Fig. 5c) relatively slender; coxa with tuft of setobranchs and small epipodite; basis about as long as wide, with well-marked exopodite overreaching carpo-meral articulation; ischium about 2.5 times as long as wide, with well-marked distoventral spine; merus about 7 times as long as wide, with 4 or 5 well-marked spines along ventral margin; carpus relatively slender, about 7 times as long as wide, slightly widening distally, about twice shorter than merus and propodus, with small subdistal spine; propodus about 12-13 times as long as wide, with straight margins, armed with 10-11 spines along ventral margin; dactylus (Fig. 5d) about 3 times longer than wide, biunguiculate; ventral margin armed with 4-5 small spines, main unguis smooth, curved and sharp, accessory unguis sharp, about twice larger than ventral teeth, about twice shorter than main unguis.

Pereiopod IV (Fig. 5e) generally similar to pereiopod III; coxa with tuft of setobranchs and small epipodite; basis about as long as wide, with well-marked exopodite overreaching carpo-meral articulation, 
smaller than in pereiopod III; ischium about 2 times as long as wide, with well-marked distoventral spine; merus about 7 times as long as wide, armed with 4 spines; carpus about 5 times as long as wide, armed with small subdistal spine; propodus about 12-13 times as long as wide, with straight margins, armed with 10-11 spines along ventral margin; dactylus about 3 times longer than wide, biunguiculate; ventral margin armed with 4-5 small spines, main unguis smooth, curved and sharp, accessory unguis sharp, about twice larger than ventral teeth, about

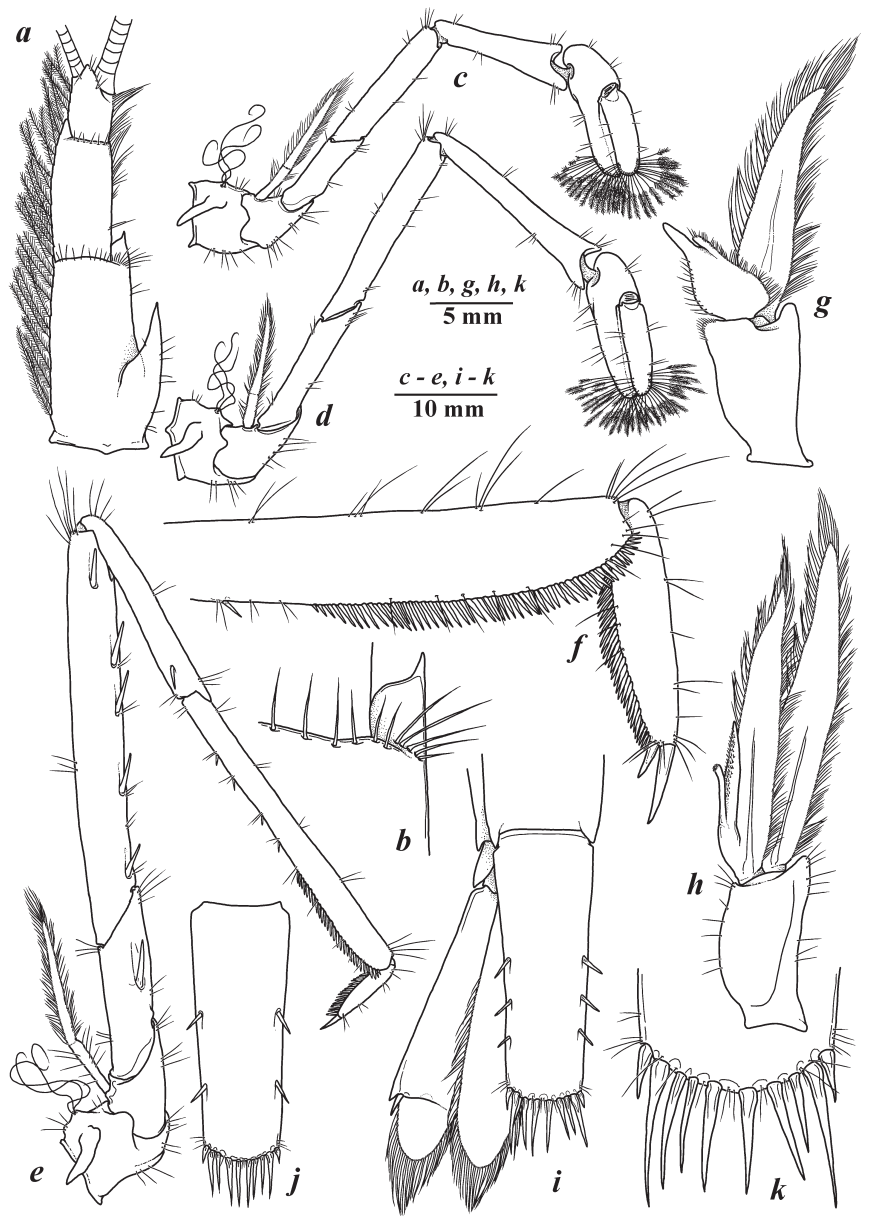

Fig. 4. Xiphocaridinella kelasuri sp. nov., ふૈ, pcl. 5.2 mm, tl. 17 mm, LEMMI, from Pakchuchaya Cave, Central Abkhazia, southwestern Caucasus: a - antennula, b - same, distolateral margin of basal segment; c - pereiopod I; d - pereiopod II; e - pereiopod III; f - same distal margin of propodus and dactylus; $\mathrm{g}$ - pleopod I; $\mathrm{h}$ - pleopod II; $\mathrm{i}$ - telson and uropods; j - telson; k - distal margin of telson.

Pleopod I (Fig. 4g) in males with endopod bearing well marked appendix interna. Pleopod II (Fig. 4h) in males with well-developed appendix interna and appendix masculina; appendix masculina covered with numerous small sharp stout simple spines. Pleopods I and II in females normal, characteristic for the genus without specific differentiating features.

Uropods (Fig. 4i) relatively stout, slightly exceeding telson; lateral margin of uropodal exopodite straight, with sharp triangular distolateral angle and 1 large distolateral spine; dieresis simple, without spines.

Coloration. Body and appendages of shrimps are translucent white or yellowish in color; cornea of eyes is albescent; internal organs (gonads and hepatopancreas) are whitish or yellowish.

Body size. The largest collected female has tbl. 6.5 twice shorter than main unguis.

Pereiopod V (Fig. 5f) generally similar to pereiopods III-IV, but without armature on basal segments and exopodite on basis; segments covered with simple setae dorsally and ventrally; propodus about 10 times as long as wide, with straight margins, armed with 7-8 spines along ventral margin and pair of long slender spines at distoventral angle; dactylus (Fig. 5g) with ventral margin armed with a dense "brush" consisting of small simple sharp setae; without accessory unguis, main unguis curved, triangular, sharp distally.

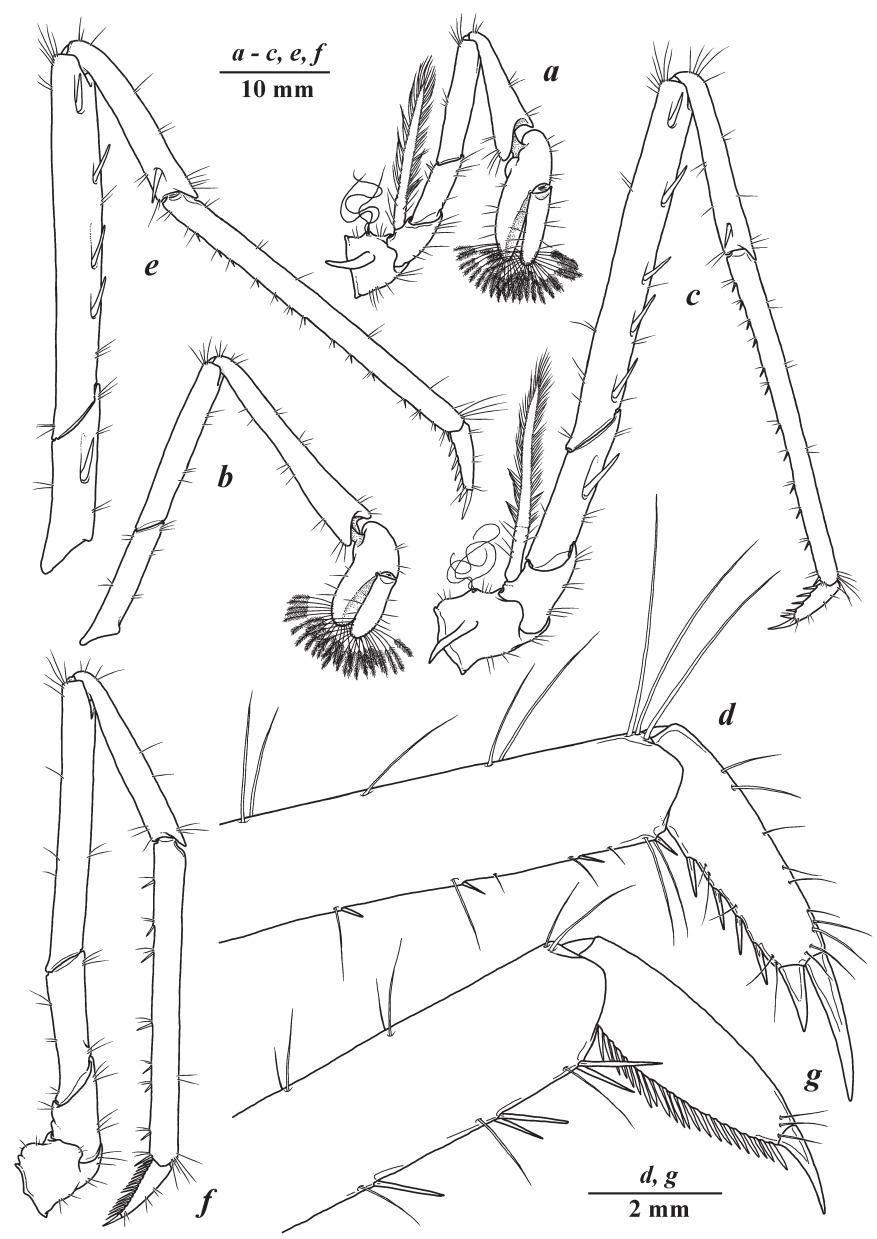

Fig. 5. Xiphocaridinella kelasuri sp. nov.,, , pcl. $5.4 \mathrm{~mm}$, tl. $18 \mathrm{~mm}$, LEMMI, from Pakchuchaya Cave, Central Abkhazia, southwestern Caucasus: a - pereiopod I, b - pereiopod II; c - pereiopod III; $\mathrm{d}$ - same, distal part of propodus and dactylus; e - pereiopod IV; $\mathrm{f}$ - pereiopod V; $\mathrm{g}$ - same, distal part of propodus and dactylus.

$\mathrm{mm}$, pcl. $21.0 \mathrm{~mm}$; the largest collected male has tbl. $6.0 \mathrm{~mm}$, pcl. $20.0 \mathrm{~mm}$.

Etymology. The species is named after the Kelasur River, Central Abkhazia, southwestern Caucasus.

GenBank accession numbers. OK044085-OK044093. Distribution. The species is known from three distant caves in Central Abkhazia of the southwestern Caucasus that have a hydrogeological connection -

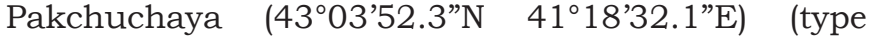
locality), Kelasurskaya $\left(43^{\circ} 02^{\prime} 48.8^{\prime \prime} \mathrm{N} 41^{\circ} 09^{\prime} 36.0\right.$ "E) and Besletka $\left(43^{\circ} 01^{\prime} 48.1^{\prime \prime} \mathrm{N} 41^{\circ} 04^{\prime} 36.0^{\prime \prime} \mathrm{E}\right)$ caves

Taxonomic remarks. The new species is phylogenetically close to $X$. smirnovi, Xiphocaridinella otapi Marin, 2018 and Xiphocaridinella shurubumu Marin, 2018 (Fig. 1) also having a relatively short rostrum that slightly extends beyond the distal margin of the 
basal antennular segment (Marin, 2018a, 2020). In all these species rostrum is triangular, armed $(X$. smirnovi) or unarmed (X. otapi and $X$. shurubumu) dorsally. Most of studied individuals of the new species have unarmed rostrum (Figs 2, 3d-g), whereas several large females from the Kelasurskaya Cave (Fig. 3a-c) have small fixed teeth in the distal part of the rostrum and several movable spines in the medial part of the rostrum dorsally. Nevertheless, the presence of several dorsal rostral spines compared to the mostly unarmed rostrum in X. otapi (Marin, 2018a: Figs 9, 10a-e) and $X$. shurubumu (Marin, 2018b: Figs 3, 4) can be a distinguished feature of the new species. The dorsal spines on telson in the new species are situated at about 0.4 and 0.7 of telson length, while at about 0.5 and 0.7 of telson length in $X$. smirnovi (Marin, 2020: Fig. 7f), about 0.4 and 0.6 in $X$. otapi (Marin, 2018a: Fig. 10f, g) and 0.25 and 0.5 of telson length in $X$. shurubumu (Marin, 2018b: Fig. 5g, h) that is also can be used as a diagnostic feature.

Nevertheless, the morphology (the length and shape of rostrum, telson and position of its dorsal spines) of almost all species of the genus Xiphocaridinella greatly varies (e.g., Xiphocaridinella kumistavi Marin, 2017 (Marin, 2017a) or present paper), and sometimes intraspecific morphological differences overlap interspecific ones. This can probably be explained by the absence of predators in the caves and, consequently, selection by certain morphological features, as, for example, in the case of Troglocaris cooccurring with the predatory blind cave salamander Proteus anguinus Laurenti, 1768 (Amphibia: Proteidae) (Jugovic et al., 2010). Therefore, the most convenient and accurate way to identify the species is to compare the cytochrome $\mathrm{c}$ oxidase subunit I (COI) mtDNA gene marker, i.e., barcoding.

\section{DISCUSSION}

Based on the above theoretical literature (conclusions), and partly on the results of experimental data on groundwater staining, it was assumed the presence of a complex and very long karst hydrogeological system in Central Abkhazia. The sources of this system are located in the Kodor River basin of the Amtkel karst system, from which part of the groundwater flows in transit through the Kelasur River basin and is subsequently discharged into the Besletka River basin, partly into the Besletka Cave (Kipiani \& Tintilizov, 1960; Kiknadze, 1978; Tatashidze et al., 2009). The existence of this karst hydrological system was first shown on the basis of integrative studies of stygobiotic shrimp $X$. falcirostris, found in the Nizhne-Shakuranskaya Cave (located on the Shakuran Stream, a tributary of the Kodor River) and the Besletka Cave (located in the lower reaches of the Besletka River) (Marin, 2020).

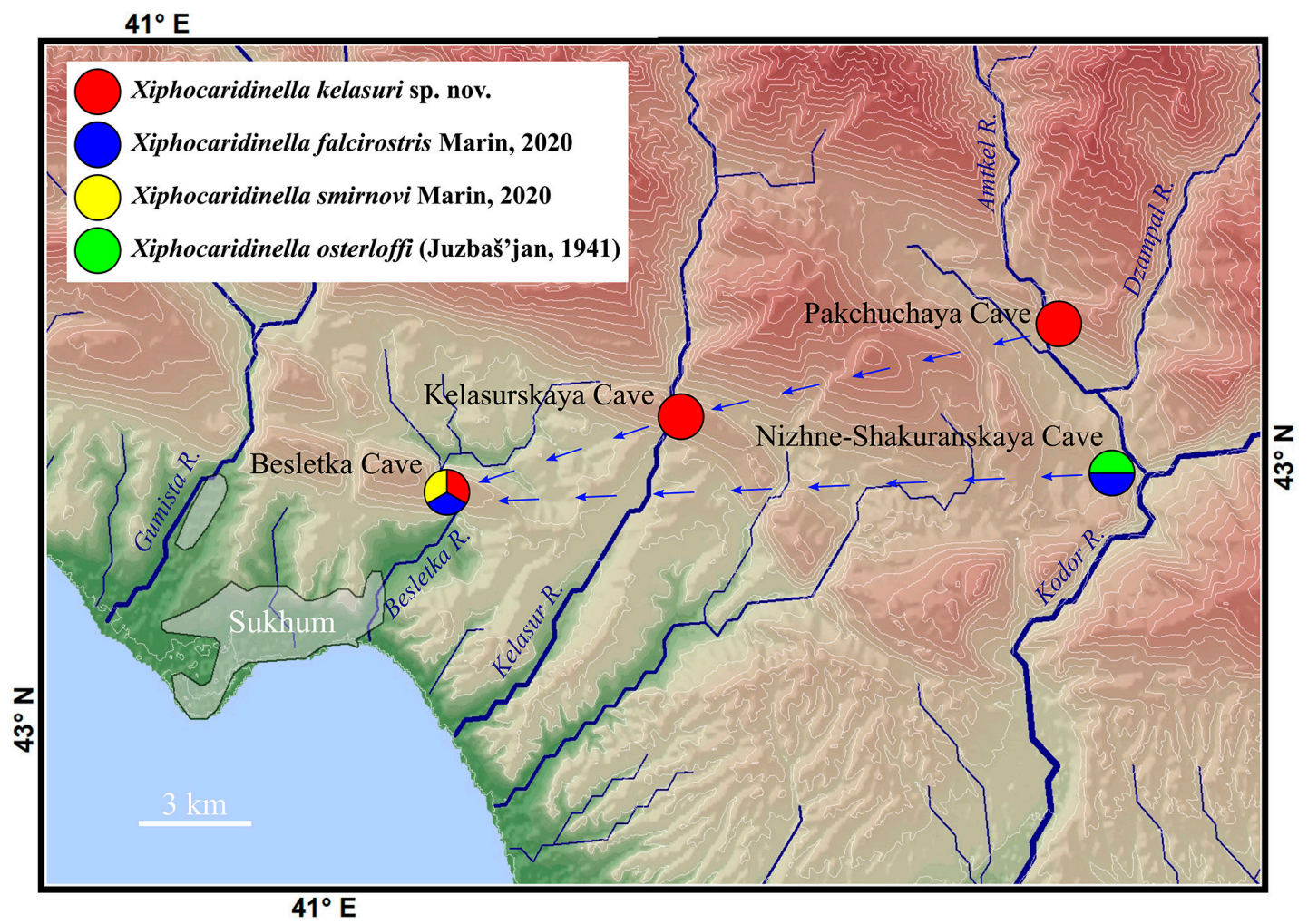

Fig. 6. The map of the distribution of stygobiotic shrimps of the genus Xiphocaridinella in the caves of Central Abkhazia, indicating the estimated flow directions of underground (subterranean) rivers (blue arrows).

It should be noted that Caucasian stygobiotic shrimps of the genus Xiphocaridinella have already been found living sympatrically in Central Abkhazia (Fig. 6): three species were found in the Besletka Cave - Xiphocaridinella kelasuri sp. n., X. falcirostris and $X$. smirnovi (Marin, 2019a; this study); two species, $X$. falcirostris and $X$. osterloffi, in the Nizhne-
Shakuranskaya Cave (Marin, 2019a); two species, Xiphocaridinella ablaskiri (Birštein, 1939) and X. otapi were found in the Golova Otapa and Abrskila caves (Marin, 2018a). Records of sympatric species among Xiphocaridinella can shed light on the hydrogeological relationships of amongst different karst systems in other parts of the Caucasus: Xiphocaridinella dbari 
Marin, 2019 was observed in Arabika Karst Massif (Western Abkhazia), at the bottom section of the Veryovkina and Gegskaya caves (Marin, 2019a); it is likely that the same species was referred to as Troglocaris sp. for the bottom part of the cave Krubera (=KruberaVoronya) Cave (Sendra \& Reboleira, 2012); X. ablaskiri is recorded for local epikarst watercourse connecting closely located caves Kolodez 75 Metrov, Samshitovaya, Uatapakhy, and Golova Otapa in the Eastern Abkhazia (Marin, 2018a). Similar sympatric habitats of stygobiotic shrimps are known outside the Caucasus and in other regions of Europe (Cobolli Sbordoni et al., 1990; Sket \& Zakšek 2009; Jugovic et al., 2012).

However, presently described Xiphocaridinella kelasuri sp. n. was found only in Pakchuchaya, Kelasurskaya, and Besletka caves, whereas $X$. falcirostris exists only in the Nizhne-Shakuranskaya and Besletka caves. This suggests a lack of hydrological connections between caves located on the Shakuran and Amtkel Rivers within the Amtkel karst system, in addition to the proven connection of these caves through epikarst unloading the Shavtskala Cave (Amelichev et al., 1990, 2007), where Xiphocaridinella shrimp has not yet been discovered. However, as previously suggested (Kiknadze, 1978), part of the underground water of the Amtkel karst system flows developed tectonic disturbances in the southwestern direction. In our opinion, there are at least two parallel hydrological systems in the Amtkel karst system (Fig. 6): the first, inhabited by $X$. falcirostris - from the caves on the Shakuran River in the Kodor River basin in the direction of the Besletka Cave in the Besletka River basin; and the second, inhabited by Xiphocaridinella kelasuri sp. n. - from the caves on the Amtkel River in the direction of the Besletka Cave with a proven intermediate link in the Kelasurskaya Cave. At the same time, it is possible that the identified karst hydrogeological system may be much more complex, as evidenced by the presence of $X$. smirnovi in the Besletka Cave (Marin, 2020), which has so far been found only in this cave, but not in the caves of the Amtkel karst system. Perhaps, the Besletka Cave is the final link (karst collector), where underground water is discharged not only from the Amtkel karst system, but also from other karst massifs located in the upper reaches of the Besletka, or even Gumista or Kelasur rivers, where most likely $X$. smirnovi lives. However, to confirm this hypothesis, it is necessary to collect additional material of stygobiotic shrimps of the genus Xiphocaridinella in the specified area, other caves of the Western Abkhazia.

We believe that such a biospeleological method allows us to establish biogeographic connections between underground water flows and can be used on a par with traditional hydrogeological methods (Ford \& Williams, 2007; Goldscheider et al., 2008). Moreover, this method can be used not only on the example of stygobiotic atyid shrimp, whose habitat is limited to certain karst regions, but also for other representatives of the stygobiotic animals, for example, crabs (Stemmer \& Schubart, 2016) and the widespread amphipods of the genus Niphargus Schiødte, 1847 (Crustacea: Amphipoda: Niphargidae).

\section{ACKNOWLEDGEMENTS}

The study is supported by the Russian Foundation for Basic Research (grant № 20-04-00803_A) (IM) and within the framework of the State Assignment No. 121051100109-1 (IT). Authors are very grateful to S. Sinelnikov (Moscow), A. Koval (Saint-Petersburg), and S. Bogdanenko (Sevastopol) for their help during sampling in Abkhazia; O. Artaev (Saransk) for the assistance in preparing the topographical basis for the map-scheme of stygobiotic shrimps distribution. Dr. Alejandro Martinez and an anonymous reviewer, made many important comments that significantly improved the manuscript.

Authorship statement: IM and IT sampling and DNA extraction; IM phylogenetic analysis, taxonomic part and species description; IT karstological and hydrogeological part.

\section{REFERENCES}

Amelichev, G.N., Dublyansky, V.N., Vakhrushev, B.A., 1990. The system of karst aquifers Amtkel (conditions of origin, functioning and development. M.V. Frunze Simferopol State University, Simferopol, 38 p. Deposited in the Ukrainian Research Institute for Scientific and Technical Information 21.05.1990, No. 895-Uk90 [in Russian].

Amelichev, G.N., Vakhrushev, B.A., Dublyansky, V.N., 2007. Hydrodynamics and evolution of speleomorphogenesis of the Amtkel karst system (Western Abkhazia). Geopolitica i Ecogeodynamika Regionov, 2, 52-60 [in Russian].

Avise, J.C., 1993. Molecular markers. Natural history and evolution. Chapman \& Hall, New York, 511 p. https://doi.org/10.1046/j.1420-9101.1994.7060766.x

Bandelt, H., Forster, P., Röhl, A., 1999. Median-joining networks for inferring intraspecific phylogenies. Molecular Biology and Evolution, 16(1), 37-48.

https://doi.org/10.1093/oxfordjournals.molbev. a026036

Birštein, Ya.A., 1939. O peshernysh krevetkah Abhazii [About cave shrimps of Abkhazia]. Zoologichesky Zhurnal, 18(6), 960-974 [in Russian].

Birštein, Ya.A., 1948. O nahozdenii pesherinoy krevetki Troglocaris v gruntovyh vodah Mazesty i svazannye s etim voprosy [The occurrence of the cave shrimp Troglocaris in underground water of Mazesta and related problems]. Byulleten' Moskovskogo Obshchestva Ispytatelei Prirody, Otdel Biologicheskii, 53(3), 3-10 [in Russian].

Cobolli Sbordoni, M., Mattoccia, M., La Rosa, G., De Matthaeis, E., Sbordoni, V., 1990. Secondary sympatric occurrence of sibling species of subterranean shrimps in the Karst. International Journal of Speleology, 19(1), 9-27. http://dx.doi.org/10.5038/1827-806X.19.1.2

Dublyansky, V.N., Klimchouk, A.B., Kiselev, V.E. Vakhrushev, B.A., Kovalev, Yu.I., Melnik, V.P., Ryzhkov, A.F., Tintilozov, Z.K., Chuikov, V.D., Churubrova, M.L., 1987. Large karstic cavities of the USSR. III. Speleological provinces of the Greater and Lesser Caucasus. AS UkrSSR editorial team "Geological Journal". Kiev, 80 p. Deposited in the All-Soviet Institute for Scientific and Technical Information 06.01.1987, No. 32792 [in Russian].

Folmer, O., Black, M., Hoeh, W., Lutz, R., Vrijenhoek, R., 
1994. DNA primers for amplification of mitochondrial cytochrome c oxidase subunit 1 from diverse metazoan invertebrates. Molecular Marine Biology and Biotechnology, 3(5), 294-299.

https://doi.org/10.1371/journal.pone.0199609

Ford, D.C., Williams, P.W., 2007. Karst hydrogeology and geomorphology. Wiley, New York, $562 \mathrm{p}$.

Gigineiyshvili, G.N., 1979. Karst waters of the Greater Caucasus and the main problems of karst hydrology. Menciereba, Tbilisi, $222 \mathrm{p}$ [In Russian].

Goldscheider, N., Meiman, J., Pronk, M., Smart, C., 2008. Tracer tests in karst hydrogeology and speleology. International Journal of Speleology, 37(1), 27-40. http://dx.doi.org/10.5038/1827-806X.37.1.3

Hebert, P.D.N., Cywinska, A., Ball, S.L., De Waard, J.R., 2003. Biological identifications through DNA barcodes. Proceedings of the Royal Society of London B, 270, 313-322.

https://doi.org/10.1098/rspb.2002.2218

Jugovic, J., Prevorcnik, S., Aljancic, G., Sket, B., 2010. The atyid shrimp (Crustacea: Decapoda: Atyidae) rostrum: phylogeny versus adaptation, taxonomy versus trophic ecology. Journal of Natural History, 44(41-42), 2509-2533.

https://doi.org/10.1080/00222933.2010.502258

Juzbašjan, S.M., 1940. O Shakuranskoy pesernoy krevetke [On Shakuran cave shrimp]. Trudy biologiceskoj stancii Narkomprosa Gruzinskoj SSR, 1, 73-86 [in Russian].

Juzbašjjan, S.M., 1941. O podvidah i mezvidovyh razlichyayh u Troglocaris kutaissiana Sadowsky. Soobshenie I [On the subspecies and intraspecific differentiation in Troglocaris kutaissiana Sadowsky. Communication I]. Soobshcheniya Akademii Nauk Gruzinskoy SSR, 2(10), 929-935 [in Russian].

Kimura, M., 1980. A simple method for estimating evolutionary rates of base substitutions through comparative studies of nucleotide sequences. Journal of Molecular Evolution, 16(2), 111-120. https://doi.org/10.1007/BF01731581

Kiknadze, T.Z., 1978. O podzemnykh basseynakh karstovykh vod i intensivnosti karstovykh protsessov mezhdurechia Kelasuri-Kodori [About underground basins of karst waters and the intensity of karst processes in the Kelasuri-Kodori interfluve]. Caves of Georgia, 7, 12-21 [In Russian].

Kipiani, Sh.Ya., Tintilizov Z.K., 1960. Podruslovye karstovye peshchery Kelasuri [Kelasuri Underflow Karst Caves]. Soobshcheniya Akademii Nauk Gruzinskoy SSR, 25(6), 685-692 [In Russian].

Knowlton, N., Weigt, L.A., 1998. New dates and new rates for divergence across the Isthmus of Panama. Proceedings of the Royal Society of London. Series B, 265, 2257-2263. https://doi.org/10.1098/rspb.1998.0568

Knowlton, N., Weight, L.A., Solorzano, L.A., Mills, D.K., Bermingham, E., 1993. Divergence in proteins, mitochondrial DNA and reproductive compatibility across the Isthmus of Panama. Science, 260, 16291632. https://doi.org/10.1126/science.8503007

Kozlov, A.M., Darriba, D., Flouri, T., Morel, B., Stamatakis, A., 2019. RAxML-NG: A fast, scalable, and user-friendly tool for maximum likelihood phylogenetic inference. Bioinformatics, btz305.

https://doi.org/10.1093/bioinformatics/btz305

Kumar, S., Stecher, G., Tamura, K., 2016. MEGA7: Molecular evolutionary genetics analysis Version 7.0 for bigger datasets. Molecular Biology and Evolution, 33(7), 1870-1874. https://10.1093/molbev/msw054
Lanfear, R., Frandsen, P.B., Wright, A.M., Senfeld, T., Calcott, B., 2016. PartitionFinder 2: New methods for selecting partitioned models of evolution formolecular and morphological phylogenetic analyses. Molecular Biology and Evolution, 34(3), 772-773 https://doi.org/10.1093/molbev/msw260

Lefébure, T., Douady, C.J., Gouy, M., Trontelj, P., Briolay, J., Gibert, J., 2006. Phylogeography of a subterranean amphipod reveals cryptic diversity and dynamic evolution in extreme environments. Molecular Ecology, 15, 1797-806. https://doi.org/10.1111/j.1365-294X.2006.02888.x

Lefébure, T., Douady, C. J., Malard, F., Gibert, J., 2007. Testing dispersal and cryptic diversity in a widely distributed groundwater amphipod (Niphargus rhenorhodanensis). Molecular Phylogenetics and Evolution, 42, 676-686. https://doi.org/10.1016/j.ympev.2006.08.020

Leigh, J.W., Bryant, D., 2015. PopART: Full-feature software for haplotype network construction. Methods in Ecology and Evolution, 6(9), 1110-1116.

https://doi.org/10.1111/2041-210X.12410

Linke, S., Lehner, B., Dallaire, C.O., Ariwi, J., Grill, G., Anand, M., Beames, P., Burchard-Levine, V., Maxwell, S., Moidu, H., Tan, F., Thieme, M., 2019. Global hydro-environmental sub-basin and river reach characteristics at high spatial resolution. Scientific Data, 6, 1-15.

https://doi.org/10.1038/s41597-019-0300-6

Marin, I., 2017a. Troglocaris (Xiphocaridinella) kumistavi sp. nov., a new species of stygobiotic atyid shrimp (Crustacea: Decapoda: Atyidae) from Kumistavi Cave, Imereti, Western Georgia, Caucasus. Zootaxa, 4311(4), 576-588. https://doi.org/10.11646/zootaxa.4311.4.9

Marin, I.N., 2017b. COXI based phylogenetic analysis of Caucasian clade of European Troglocaris s.1. (Crustacea: Decapoda: Atyidae) with the suggestion of a new taxonomic group structure. Biosystems Diversity, 25(4), 323-327. https://doi.org/10.15421/011749

Marin, I., 2018a. Cryptic diversity of stygobiotic shrimp genus Xiphocaridinella Sadowsky, 1930 (Crustacea: Decapoda: Atyidae): the first case of species cooccurrence in the same cave system in the Western Caucasus. Zootaxa, 4441(2), 201-224.

https://doi.org/10.11646/zootaxa.4441.2.1

Marin, I., 2018b. Xiphocaridinella shurubumu Marin sp. n. (Crustacea: Decapoda: Atyidae) - a new stygobiotic atyid shrimp species from Shurubumu and Mukhuri caves, Chkhorotsku, Western Georgia, Caucasus. Zoologichesky Zhurnal, 97(10), 1238-1256.

https:// doi.org/10.1134/S0044513418100082

Marin, I.N., 2019a. Crustacean "cave fishes" from the Arabika karst massif (Abkhazia, Western Caucasus): new species of stygobiotic crustacean genera Xiphocaridinella and Niphargus from the Gegskaya Cave and adjacent area. Arthropoda Selecta, 28(2), 225-245. https://doi.org/10.15298/arthsel. 28.2.05

Marin I.N., 2019b. A new stygobiotic Xiphocaridinella (Crustacea: Decapoda: Atyidae) from the Motena Cave, Samegrelo-Zemo Svaneti region of Georgia, Caucasus. Zootaxa 4648(3), 592-600.

https://doi.org/10.11646/zootaxa.4648.3.12

Marin, I.N., 2020. Stygobiotic atyid shrimps (Crustacea, Decapoda, Atyidae) from the Amtkel karst system, western Abkhazia, Caucasus, with a redescription of Xiphocaridinella osterloffi and the description of two new co-occurring species. Zoologicheskyi Zhurnal, 99(11), 1203-1222.

https://doi.org/10.31857/S0044513420100128 
Marin, I.N., Sinelnikov S.Yu., 2017. Preliminary data on larval development of Caucasian cave-dwelling shrimp Troglocaris (Xiphocaridinella) kumistavi Marin, 2017 (Crustacea: Decapoda: Atyidae). Arthropoda Selecta, 26(4), 297-302. https://doi.org/10.15298/arthsel.26.4.03

Marin, I., Sokolova, A., 2014. Redescription of the stygobiotic shrimp Troglocaris (Xiphocaridinella) jusbaschjani Birštein, 1948 (Decapoda: Caridea: Atyidae) from Agura River, Sochi, Russia, with remarks on other representatives of the genus from Caucasus. Zootaxa, 3754(3), 277-298.

https://doi.org/10.11646/zootaxa.3754.3.3

Sadowsky, A.A., 1930. Xiphocaridinella kutaissiana nov. gen. et sp. (Fam. Atyidae) aus einer unterirdischen Höhle bei Kutais. Zakavkazskij kraevedstenny sbornik naučnoissledovatel'nogo kraevedstvenogo kabineta Universiteta Tiflis, 1, 93-104 [in Russian with German abstract].

Sendra, A., Reboleira, A.S.P.S., 2012. The world's deepest subterranean community - Krubera-Voronja Cave (Western Caucasus). International Journal of Speleology, 41(2), 221-230. https://doi.org/10.5038/1827-806X.41.2.9

Sites, J.W., Marshall, J.C., 2004. Operational criteria for delimiting species. Annual Review of Ecology, Evolution and Systematics, 35, 199-227.

https://doi.org/10.1146/annurev. ecolsys.35.112202.130128

Sket, B., Zakšek, V., 2009. European cave shrimp species (Decapoda: Caridea: Atyidae), redefined after a phylogenetic study; redefinition of some taxa, a new genus and four new Troglocaris species. Zoological Journal of the Linnaean Society, 155, 786-818. https://doi.org/10.1111/j.1096-3642.2008.00473.x

Stemmer M., Schubart C.D., 2016. Genetic analyses determine connectivity among cave and surface populations of the Jamaican endemic freshwater crab Sesarma fossarum in the Cockpit Country. International Journal of Speleology, 45(1), 35-41. http:/ /dx.doi.org/10.5038/1827-806X.45.1.1912

Tatashidze, Z.K., Tsikarishvili, K.D., Jishkariani, J.M., 2009. The cadastre of the karst caves of Georgia. Petiti Publishing House, Tbilisi, 670 p. [in Georgian].

Tintilozov, Z.K. 1976. Karst caves of Georgia. Menciereba, Tbilisi, 273 p. [In Russian].

Zakšek V., Sket B., Trontelj P., 2006. Phylogeny of the cave shrimp Troglocaris: Evidence of a young connection between Balkans and Caucasus. Molecular Phylogenetics and Evolution, 42, 223-235. https://doi.org/10.1016/j.ympev.2006.07.009 